\title{
DOES NATIONALITY OF OWNERSHIP MATTER FOR LABOR DEMANDS?
}

Francesca Fabbri

University College London

Jonathan E. Haskel

Queen Mary, University of London, and CEPR

\author{
Matthew J. Slaughter \\ Tuck School of Business at Dartmouth \\ and NBER
}

\begin{abstract}
Do multinational firms exhibit different patterns of labor demand from purely domestic firms? Many standard models of trade and multinational companies suggest one such difference may be labor-demand elasticities. For several reasons, multinationals may have more-elastic labor demands than do purely domestic firms. In this paper we discuss the theory issues involved. We then present industry-levelevidence that, for U.K. and U.S. manufacturing, labor demand for less-skilled labor has become more elastic in recent decades-a period in which for both countries multinational activity has expanded. (JEL: F2, L1)
\end{abstract}

\section{Introduction}

One of the most important recent labor-market developments has been the rise in wage inequality in many OECD countries. The two main candidates to explain such changes, technology and globalization, have been subject to extensive empirical investigation, see e.g., surveys by Haskel (2000) and Slaughter (1999). Although many favor the technology explanation there is still controversy over the issue.

Much of this work looks at the impact of globalization on shifting the price of labor. This paper aims to broaden the globalization and wages debate by looking at the effect of globalization-in particular, the effect of multinational firms and related trade- on the elasticity of labor demand. The idea is simple. With the spread of multinationals and increased trade in goods, firms may face more competitive goods markets. With the spread of global production networks

Acknowledgments: For very helpful discussion we thank Patty Anderson. The data in this paper were used as part of the U.K. Office of National Statistics business-data-linking project. For data assistance we thank Ralf Martin. For financial support Haskel and Fabbri thank the U.K. Economic and Social Research Council for grant \#R000223239, and Slaughter thanks the National Science Foundation. For helpful comments we thank session participants at the 2002 European Economic Association meetings.

E-mail addresses: Fabbri: f.fabbri@ucl.ac.uk; Haskel: j.e.haskel@qmul.ac.uk; Slaughter: matthew. slaughter@dartmouth.edu. 
mediated largely by multinationals, firms can more easily transfer production abroad in response to wage changes. For both these reasons, labor demand can become more elastic.

There are three points immediately worth noting concerning this argument. First, the argument is perfectly consistent with globalization having no effect on wages. The argument here is that globalization has changed the slope of the labor-demand curve, not its position. Second, note that this argument holds whether global integration is with developed or developing countries. This is important, because many have pointed out that for many developed countries trade with developing countries is still relatively small (although it may be important on the margin). Third, the focus of this work is on the labor-market impacts of multinational firms. In the literature on globalization and labor markets, the impact of these firms has been much less researched than has the role of trade and immigration. This relative lack of attention is unfortunate because it is the multinationalization of production to which a number of scholars have pointed as the distinguishing feature of the current phase of globalization compared to previous episodes (e.g., Bordo, Eichengreen, and Irwin 1999).

As Rodrik (1997) and others have pointed out, an increase in labor demand elasticities is potentially important. First, an increase in elasticities may help explain another important OECD labor-market development: the rise in job insecurity. There is now a large body of evidence that labor-market volatility has been rising in many countries, especially in the 1990s, in terms of greater earnings volatility, declining job tenure, and self reports (e.g., OECD 1997). Gottschalk and Moffitt (1994) report substantial increases in year-to-year earnings volatility for the United States over the 1970s and 1980s. Looking at the 1990s as well, a symposium issue of the Journal of Labor Economics (1999) documented declines in U.S. job stability, especially in the 1990s for large groups of workers such as those with more tenure. Within that symposium issue, Schmidt's (1999) analysis of individual surveys finds that U.S. workers in the 1990s were more pessimistic about losing their jobs than they were during the 1980s. A wide range of surveys have found evidence of rising job insecurity over the 1990s relative to earlier decades, despite the ongoing economic expansion (e.g., Bronfenbrenner 2000).

Second, a rise in labor demand elasticities may be helpful in understanding the evolution of wage bargaining, an important aspect of labor-market outcomes. There is a large literature in labor economics that has documented a robustly positive correlation between wages for various micro-units-firms, individuals, union-firm bargaining units-with profits per worker at the level of that microunit's firm and/or industry. These profits are interpreted as "prosperity in the product market" enjoyed by firms and available for sharing with workers based on negotiations with firms. Most studies of profit sharing simply assume to be constant the key parameter of the bargaining power of workers relative to firms. But in reality, it is very plausible that greater activity by multinationalsand thus greater labor-demand elasticities-lowers this power. 
Third, such a rise matters for policy. A rise could mean that the natural rate of unemployment has fallen since wage pressure would be reduced for a given level of unemployment (Layard, Nickell, and Jackman 1991). Of course a complete picture of changes in the natural rate would have to account for other changes in, for example, the structure of unemployment, benefits etc., but this may be part of the story. In addition, changes in elasticities would mean important changes in the incidence of taxes. The incidence of labor taxes (or their equivalent, e.g., labor standards) will fall much more on labor than on capital. Thus labor may bear the burden of increased taxes, demand for which might increase as insecurity increases.

In this paper we explore whether MNEs exhibit different labor-demand elasticities from purely domestic firms. We first lay out the basic labor-demand theory, and then discuss why multinational firms may raise elasticities. We then present industry-level evidence that for U.K. and U.S. manufacturing, labor demand for less-skilled labor has become more elastic in recent decades-a period in which for both countries multinational activity has expanded. We also discuss empirical evidence that multinationals differ on the external margin of plant shutdowns.

\section{Theory of Labor Demands and the Role of Multinational Firms}

Consider a plant with a constant returns cost function

$$
C=c\left(w_{1}, \ldots, w_{N}, T\right) Y
$$

where there are $N$ factors of production each with price $w, T$ denotes technology, and $Y$ output. The demand for labor $L$ is given by Shepherd's Lemma

$$
L=c_{w}\left(w_{1}, \ldots, w_{N}, T\right) Y
$$

The elasticity of demand for labor is given by

$$
\eta_{L L}=\frac{w}{L} \frac{\partial L}{\partial w}=\frac{w}{L} c_{w w}\left(w_{1}, \ldots, w_{N}, T\right) Y,
$$

which can be written in terms of the own elasticity of substitution and elasticities of substitution with respect to other factors as,

$$
\eta_{L L}=\theta_{L} \sigma_{L L}
$$

or

$$
\eta_{L L}=-\sum_{i=1}^{N} \theta_{i} \sigma_{L i} \quad \text { for } i \neq L
$$

where $\theta$ is the share of factor $i$ and this is for a firm with no market power.

Equations (4) and (5) say the following. First, (4) says that that $\eta$ is simply 
the share of labor times the own Allen elasticity of substitution. The share is given by the data, $\sigma$ can be estimated. Second, 5 shows that $\eta$ is equal to the elasticity of substitution between labor and another factor $j$, weighted by the share of that factor in total costs.

Equation (5) is useful in thinking about why elasticities might have changed, or might differ between types of firms. Suppose, for example, it becomes easier to import intermediate goods that were previously made by domestic labor. This is especially likely within the global production networks of multinational firms. If a firm is vertically integrated with production stages, then increased openness to foreign direct investment (FDI) and trade means that stages can move abroad either within firms by establishing multinational enterprises with foreign affiliates (e.g., Helpman 1984) or by importing the output of those stages from other firms (e.g., Feenstra and Hanson 1997). Hence $\sigma_{L M}$ rises and $\eta_{L L}$ becomes more elastic. The empirical evidence on multinational firms is consistent with this story. For the last several decades, growth of overall world trade has been driven in large part by the rapid growth of trade in intermediate inputs (e.g., Hummels, Ishii, and Yi 2001; Feenstra 1998). And Hanson, Mataloni, and Slaughter (2002) document that much of this input trade has been mediated by multinationals.

For a firm with market power, or if one is working at an industry level, (2) holds with the additional condition that $Y$ is not exogenous. Assume that $Y=$ $Y(p)$, and that $p=\lambda M C$ where $\lambda$ might be 1 with perfect competition. Then from (1), $M C=c\left(w_{1}, \ldots, w_{N}, T\right)$ and hence in differentiating (2) with respect to $w$ there is an extra term in (4)

$$
\eta_{L L}=s_{L} \sigma_{L L}-s_{L} \tau
$$

and this is the two factor case with $s_{L}$ the share of labor and $\tau$ is the elasticity of product demand $(\tau<0)$.

Equation (6) summarizes what Hamermesh (1993) calls "the fundamental law of factor demand" (p. 24). The first effect is the substitution effect, reflecting the ability to substitute towards other factors, at given output. The second is the scale effect, reflecting Marshall's second law, namely that labor is a derived demand and so output depends on conditions in the product market.

The scale effect is likely to be important, and globalization via multinational firms may have made the elasticity of labor demand more elastic by increasing the elasticity of product demand (in absolute value). Many models predict that FDI and its related international trade make a country's product markets more competitive. Through the scale effect, this should make labor demands more elastic. For example, liberalization of investment policies can force domestic firms to face heightened foreign competition. Or developments abroad related to multinationals (e.g., capital accumulation via FDI) can be communicated to domestic producers as more-intense foreign competition. In these cases more competitive product markets mean that a given increase in wages and thus costs translate into larger declines in output and thus demand for all factors. Different 
models predict different magnitudes of FDI and/or trade's impact on productmarket demand. ${ }^{1}$

\section{Empirical Results}

\subsection{Estimating Equations and Data}

To estimate labor-demand elasticities, we follow many studies in the literature (see Hamermesh 1993) by estimating a log-log regression of labor quantities on labor prices. This allows one to interpret the coefficient estimates on labor prices directly as labor-demand elasticities (with the key identifying assumption that labor is supplied perfectly elastically_-see discussion in Slaughter 2001). Thus, we report results for an equation of the form

$$
\Delta \ln L_{i t}=\sum_{i} a_{i t} \Delta \ln p_{i t}+b_{i} \Delta \ln Y_{t}
$$

where $L_{i t}$ is employment of labor type $i$ in time $t, p_{i t}$ is the price of labor type $i$ in time $t$ and $Y$ is output. In (7), $a$ varies by both labor type and time, and it is this time variation that allows for changes in the constant-output labordemand elasticity.

To estimate (7) we have industry data available, with measures of skilled labor, unskilled labor, capital and materials prices and quantities. To estimate (7) we estimate for the skilled

$$
\begin{aligned}
\Delta L_{S, b, t}=a_{S S, t} \Delta \ln \left(p_{S}\right)_{b t} & +a_{S U, t} \Delta \ln \left(p_{U}\right)_{b t}+a_{S M, t} \Delta \ln \left(p_{M}\right)_{b t} \\
& +a_{S K, t} \Delta \ln \left(p_{K}\right)_{b t}+\beta_{1 S t} \Delta T E C H_{b t}+\beta_{2 S t} \Delta \ln Y_{b t}+\epsilon_{1 b t}
\end{aligned}
$$

and for the unskilled

$$
\begin{aligned}
\Delta U_{S, b, t}=a_{U U, t} \Delta \ln \left(p_{U}\right)_{b t}+a_{U S, t} \Delta \ln \left(p_{S}\right)_{b t}+a_{U M, t} \Delta \ln \left(p_{M}\right)_{b t} \\
+a_{U K, t} \Delta \ln \left(p_{K}\right)_{b t}+\beta_{1 U t} \Delta T E C H_{b t}+\beta_{2 U t} \Delta \ln Y_{b t}+\epsilon_{1 b t}
\end{aligned}
$$

In Equations (8) and (9), the key coefficient estimates of interest are $a_{S S}$ and $a_{U U}$

1. One example is a monopolistically-competitive industry producing for Dixit-Stiglitz consumers who value product variety (e.g., Helpman and Krugman 1989). Here the representative firm is usually assumed to face a demand elasticity (greater than one) that equals the elasticity of substitution (EOS) among product varieties in consumers' utility function. But the actual demand elasticity is only approximately equal to the EOS. It equals EOS plus a second term, [(1 EOS) $/ N]$, where $N$ is the number of firms in the industry. As $N$ rises - thanks, for example, to FDI by foreign MNEs - so, too, does this elasticity. In Armington-type models, where consumers regard home and foreign product varieties as imperfect substitutes, the product-demand elasticity depends on the substitution between home and foreign varieties. Trade liberalization that eases substitution increases the overall elasticity of demand. Levinsohn (1993) and Harrison (1994) using plant-level data find that trade liberalization in Turkey and the Ivory Coast reduced price-cost mark-ups. This is consistent with higher product-market demand elasticities. 
We re-report estimation results for the United States as originally reported in Slaughter (2001), and for the United Kingdom we have new results for a similar analysis. In both cases the basic data are an industry-year panel that reports prices and quantities of inputs and outputs (the CES-NBER Manufacturing Productivity Database for the United States, starting in 1958; the Oulton and O'Mahony database for the United Kingdom, with several observations over 1958-1986). For both data sets, skills are distinguished by the nonproduction/production occupation classification. We estimate (8) and (9) using three-year and five-year time differences with all manufacturing industries pooled together in each year, with many years hopefully minimizing noise from measurement error (and also hopefully removing some autocorrelation effects). See Slaughter (2001) for additional discussion.

\subsection{Estimation Results}

Figure 1, taken from Slaughter (2001), reports estimation results for U.S. production labor using three-year and five-year differencing (to represent better the underlying trends, the figure plots three-year moving averages of the estimated elasticities). The main message is that production-labor demand became markedly more elastic. This elasticity fluctuated around -0.5 until the mid-1970s, but then it declined steadily to around -1.0 by 1991 . This pattern is very consistent across both the three-year and five-year differenced specifications.

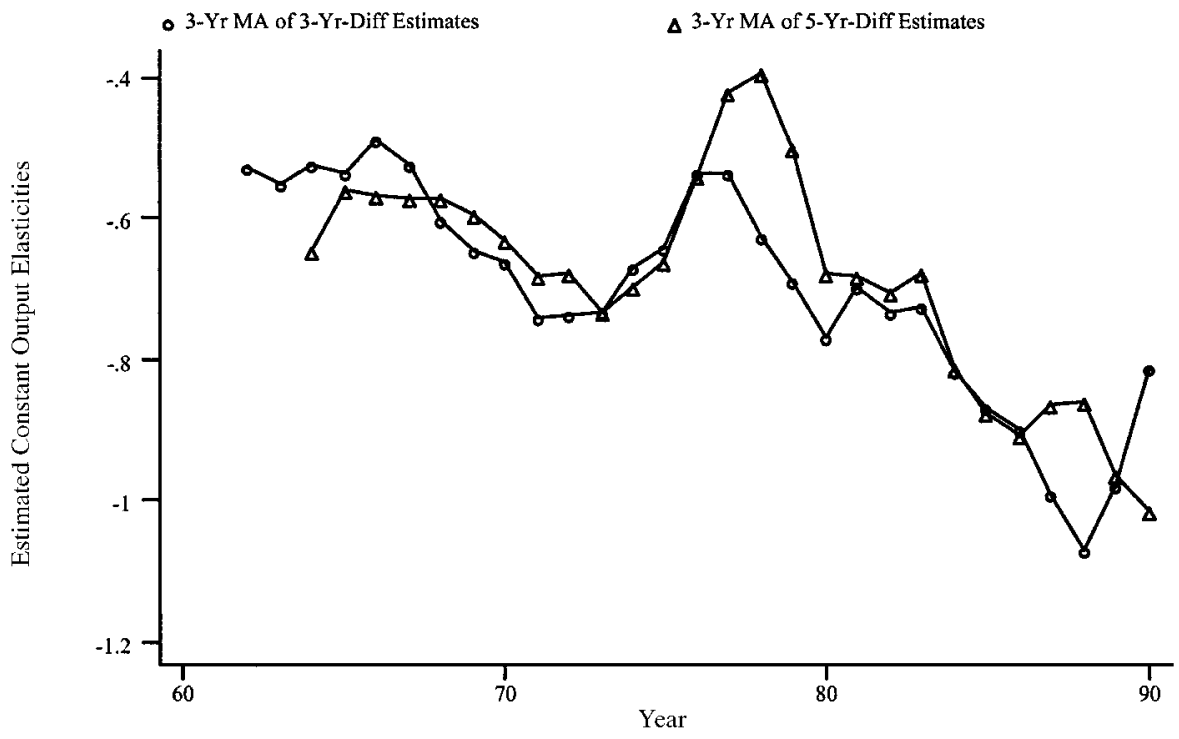

FIGURE 1. U.S. Elasticities of Labour Demand, Production Labor 


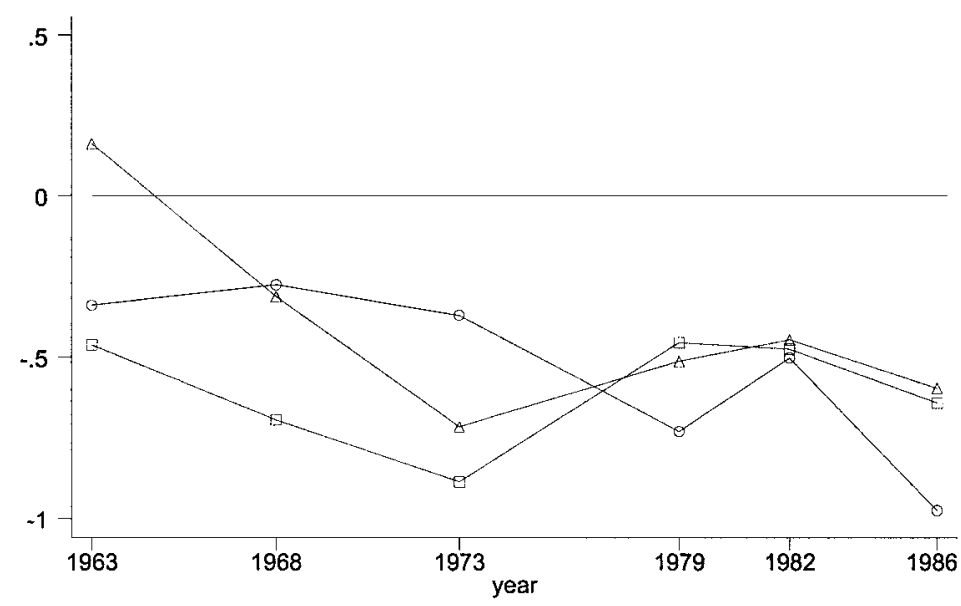

FIGURE 2. U.K. Elasticities of Labor Demand, Production and Nonproduction Labor

Figure 2 reports our similar estimation results for the United Kingdom. Here we show estimation results for both production and nonproduction labor (for brevity, the U.S. non-production results were omitted). The main message of Figure 2 is that U.K. labor demands, like those in the United States, appear to have grown more elastic over time. As in the United States, here, too, manufacturing-wide elasticities appear to have risen (in absolute value) to around unity by the mid-1980s.

What role might multinationals have played in these rising elasticities? For both countries, the trend over time in rising elasticities matched a similar trend of rising inward and outward FDI by multinationals. For example, from 1972 to 1992 the foreign-affiliate share of U.K. manufacturing employment rose from 12 percent to 23 percent. For the United States, Slaughter (2001) finds a correlation between the rise in production-labor elasticities and the share of foreign affiliates in total worldwide sales (or employment) for U.S.-headquartered multinationals (though this correlation is very sensitive to including a simple time trend). Overall, we read the evidence in Figures 1 and 2 as consistent with the hypothesis that labor demands have grown more elastic over time, perhaps in part due to rising activity by multinational firms.

\subsection{Empirical Evidence on Plant Shutdowns and Multinationals}

The idea that multinationals can more easily substitute away from labor in any one country may carry another empirical prediction: that multinationals can be more responsive not just on the intensive margin but on the extensive margin as 
well. That is, these firms might do more than substitute partially away from labor in one country, as captured by changes in labor-demand elasticities. They might substitute away entirely by closing that country's plant(s). Indeed, this extensive margin is the focus of much of the business and policy discussions about the threat that MNEs "export jobs" to affiliates via parent-country plant exits. $^{2}$ Recent general-equilibrium trade models of MNEs show that crosscountry plant relocation can be an important aspect of adjustments across equilibria (for a survey, see Markusen 2002).

This suggests the empirical hypothesis that within a country, all else equal, plants owned by MNEs are more likely to due than are plants owned by domestic firms. Do the data show this? Yes. For the plant-level U.K. data underlying the industry analysis in Figure 2, Fabbri, Haskel, and Slaughter (2002) estimate that both types of U.K. multinational plants (i.e., foreign-owned and U.K.-owned) are more likely to shut down than purely domestic U.K. plants are. Similar results are found in Gorg and Strobl (2002), who find that foreignowned plants in Irish manufacturing are more likely to exit, and in Bernard and Jensen (2002), who report higher death probabilities for plants owned by firms that hold at least 10 percent of their assets outside the United States. One common finding of these studies is the importance of conditioning on a set of operational advantages enjoyed by multinationals-e.g., older, larger, more capital-intensive - that make them less likely to shut down. But conditioning on these advantages to better isolate the effect of nationality of ownership per se finds these firms are more likely to close plants.

\section{Conclusions}

In this paper we explored whether MNEs exhibit different labor-demand elasticities from purely domestic firms. We first laid out the basic labor-demand theory, and then discuss why multinational firms may raise elasticities. We then presented industry-level evidence that for U.K. and U.S. manufacturing, labor demand for less-skilled labor has become more elastic in recent decades-a period in which for both countries multinational activity has expanded. We also discussed empirical evidence that multinationals are more likely to shut down their plants. Taken together, these findings present interesting avenues for future research-e.g., microlevel studies such as that of Navaretti, Checchi, and Turrini (2002).

2. About the North American Free Trade Agreement, Choate and Perot (1993, p. 29) write "NAFTA will accelerate the loss of manufacturing jobs in the United States. Some companies will move factories to Mexico to take advantage of low-cost Mexican labor. Others will move to Mexico to escape U.S. regulations. Many American companies will move factories to Mexico, not because they want to, but because their competitors have moved, and they must move to compete." 


\section{References}

Barba Navaretti, Giorgio, Danielle Checchi, and Alessandro Turrini (2002). "Adjusting Labor Demand: Multinational vs. National Firms, A Cross-European Analysis," mimeograph. Bernard, Andrew B. and J. Bradford Jensen (2002). "The Death of Manufacturing Plants." National Bureau of Economic Research Working Paper No. 9026.

Bordo, Michael, Barry Eichengreen, and Douglas Irwin (1999). "Is Globalization Today Really Different from Globalization a Hundred Years Ago?” Brookings Trade Forum, pp. $1-50$.

Bronfenbrenner, Kate (2000). "Uneasy Terrain: The Impact of Capital Mobility on Workers, Wages, and Union Organizing," Manuscript September. Cornell University.

Choate, Pat and H. Ross Perot (1993). Save Your Job, Save Our Country: Why Nafta Must Be Stopped-Now! New York: Hyperion Publishers.

Fabbri, Francesca, Jonathan E. Haskel, and Matthew J. Slaughter (2002). "Do Multinational Firms Have More-Elastic Labor Demands?" Mimeo.

Feenstra, Robert C. (1998). "The Integration of Trade and the Disintegration of Production." Journal of Economic Perspectives, 12(4), Fall, pp. 31-50.

Feenstra, Robert C. and Gordon H. Hanson (1997). "Foreign Direct Investment and Relative Wages: Evidence from Mexico's Maquiladoras." Journal of International Economics, 42(3-4), pp. 371-393.

Gorg, Holger and Eric Strobl (2002). "Footloose Multinationals?' Manchester School.

Gottschalk, Peter and Robert Moffitt (1994). "The Growth of Earnings Instability in the U.S. Labor Market.” Brookings Papers on Economic Activity 2. Washington, D.C.: Brookings Institution.

Hamermesh, Daniel S. (1993). Labor Demand. Princeton, New Jersey: Princeton University Press.

Hanson, Gordon H., Raymond Mataloni Jr., and Matthew J. Slaughter (2002). "Vertical Specialization in Multinational Firms," mimeo.

Harrison, Ann E. (1994). "Productivity, Imperfect Competition, and Trade Reform.” Journal of International Economics, 36, pp. 53-73.

Haskel, Jonathan E. (2000). "The Trade and Labor Approaches to Wage Inequality.” Review of International Economics.

Helpman, Elhanan (1984). "A Simple Theory of International Trade with Multinational Corporations." Journal of Political Economy, 92(3), pp. 451-471.

Helpman, Elhanan and Paul Krugman (1989). Trade Policy and Market Structure. Cambridge, Massachusetts: MIT Press.

Hummels, David, Jun Ishii, and Kei-Mu Yi (2001). "The Nature and Growth of Vertical Specialization in World Trade." Journal of International Economics, 54, pp. 75-96.

Journal of Labor Economics. (1999). Symposium Issue on "Changes in Job Stability and Job Security." October 17(4), Part 2.

Layard, Richard, Stephen Nickell, and Richard Jackman (1991). Unemployment: Macroeconomic Performance and the Labour Market. Oxford: Oxford University Press.

Levinsohn, James (1993). "Testing the Imports-As-Market-Discipline Hypothesis.” Journal of International Economics, 35, pp. 1-22.

Markusen, James R. (2002). Multinational Firms and the Theory of International Trade. Cambridge, Massachusetts: MIT Press.

Organization of Economic Cooperation and Development (1997). Jobs Outlook. Paris: OECD.

Oulton, Nick and Mary O'Mahoney (1994). Productivity and Growth: A Study of British Industry 1954-1986. Cambridge: Cambridge University Press.

Rodrik, Dani (1997). Has Globalization Gone Too Far? Washington, D.C.: Institute for International Economics. 
Schmidt, Stefanie R. (1999). "Long-Run Trends in Workers' Beliefs about Their Own Job Security." Journal of Labor Economics 17(4): pp. S127-S141.

Slaughter, Matthew J. (1999). "Globalization and Wages: A Tale of Two Perspectives." World Economy, July, 22(5), pp. 609-630.

Slaughter, Matthew J. (2001). "International Trade and Labor-Demand Elasticities.” Journal of International Economics, 54(1), pp. 27-56. 
Copyright of Journal of the European Economic Association is the property of MIT Press and its content may not be copied or emailed to multiple sites or posted to a listserv without the copyright holder's express written permission. However, users may print, download, or email articles for individual use. 